\title{
Genotype-environment interaction on baby corn production
}

\section{Interação entre genótipos e ambientes na produção de minimilho}

\author{
Gustavo André Simon ${ }^{1}$; Carlos Alberto Scapim²; Rânia Nunes Oliveira Moraes 3 ; \\ Ludmilla Ribeiro da Rocha Gomes ${ }^{3}$; Mauricio Carlos Kuki ${ }^{*}$
}

Highlights:

There is a lack of genotypes recommended for baby corn production.

Genotype $\mathrm{x}$ environment plays a major role for corn production.

Traits related with baby corn are influenced by genetic-environmental factors.

\begin{abstract}
The phase of genotype evaluation for recommendation in different environments is seen as the key stage of breeding programs, in view of the importance of the genotype - environment interaction on the main traits. The objective of this study was to evaluate different field corn, popcorn, white corn, and sweet corn genotypes for their capacity of baby corn production and the genotype - environment interaction. Twenty-nine genotypes were evaluated, in a randomized complete block design with three replications. The experiments were performed in the main and second season in Rio Verde - GO and in the second season in Maringá - PR. Significant $(\mathrm{p}<0.05)$ differences between the genotypes were observed for all evaluated traits. The genotype - environment interaction was only significant for mean ear diameter, prolificacy and ear yield, indicating a differentiated performance between genotypes in response to environmental variations. The predominance of the complex part of interaction on prolificacy and yield is emphasized. Although the baby corn harvest is performed even before ear fertilization, the results suggests that the variations in the traits related with babycorn production and quality are mainly influenced by genetic-environmental factors. The genotypes P30K64, HD 332, IPR 119, and IAC 125 obtained the highest means for the evaluated traits. The groups of white and field corn genotypes stood out for with a significantly better performance than the others, principally for ear yield.
\end{abstract}

Key words: Adaptability. Plant breeding. Zea mays L.

\section{Resumo}

A etapa de avaliação dos genótipos para a recomendação de cultivo em diferentes ambientes é uma das etapas mais importantes em programas de melhoramento, devido à importância da interação entre genótipos e ambientes que influenciam as características de interesse. O objetivo deste trabalho foi avaliar diferentes genótipos de milho, milho pipoca, milho branco e milho doce com relação a capacidade de produção de minimilho e a interação genótipos por ambientes. Foram avaliados 29 genótipos, no delineamento em blocos ao acaso com três repetições. Os experimentos foram conduzidos na safra verão e safrinha de Rio Verde - GO e na safrinha de Maringá - PR. Foram observadas diferenças

${ }^{1}$ Prof. Dr., Universidade de Rio Verde, UNIRV, Rio Verde, GO, Brasil. E-mail: simon@unirv.edu.br

2 Prof. Dr., Universidade Estadual de Maringá, UEM, Maringá, PR, Brasil. E-mail: cascapim@uem.br

3 Discentes, Curso de Graduação em Agronomia, UNIRV, Rio Verde, GO, Brasil. E-mail: rania_agro@hotmail.com; ludmilla_ rrg@hotmail.com; mcarloskuki@gmail.com

4 Discente do Curso de Doutorando do Programa de Pós-Graduação em Genética e Melhoramento, PGM/UEM, Maringá, PR, Brasil. E-mail: mcarloskuki@gmail.com

* Author for correspondence 
significativas $(p<0,05)$ entre genótipos em todas as características avaliadas e interação genótipos $\mathrm{x}$ ambientes apenas para diâmetro médio de espiguetas, prolificidade e produtividade de espiguetas, evidenciando ocorrer resposta distinta dos genótipos em função das variações ambientais. Ressalta-se a predominância da parte complexa da interação na prolificidade e produtividade de espiguetas. Embora a colheita de minimilho seja realizada antes mesmo da fecundação, os resultados sugerem que as características relacionadas a produção e qualidade de minimilho são afetadas pela interação genótipoambiente. Os genótipos P30K64, HD 332, IPR 119 e IAC 125 obtiveram as maiores médias entre as características avaliadas. Destacam-se os grupos de genótipos de milho branco e milho comum, com significativa superioridade em relação aos demais, principalmente para a produtividade de espiguetas.

Palavras-chave: Adaptabilidade. Melhoramento de plantas. Zea mays L.

\section{Introduction}

Baby corn, also known as young corn, is one of the many plant products derived from cultivated corn. Baby corn is the female inflorescence of the corn plant, i.e., stigma/styles up to $3 \mathrm{~cm}$ long that are harvested prior to fertilization (Pereira et al., 2009). Young corn can be consumed fresh, after processing by the food industry, e.g., in acidified canned form, or in pickled form.

Among the factors that influence corn cultivation for baby corn production, the most decisive is the definition of the appropriate genotype for this purpose. An appropriate genotype must be tolerant to high plant density and adapted to different seasons and have standard ears that meet the commercial requirements for the baby corn market (Pereira, Gama, \& Cruz, 1998). None of the cultivars available for the 2016/17 growing seasons were destined for baby corn production (Pereira \& Borghi, 2016). The limited resources earmarked for baby corn breeding associated with the recently expanding market in Brazil have led to a lack of cultivars developed for this purpose (Pereira et al., 1998).

To meet the demand for baby corn production, numerous field corn, popcorn, sweet corn and white corn genotypes were evaluated to identify the most appropriate genotypes for this purpose (Teles \& Nascimento, 2010; Reddy, Kumar, Sudharshan, \& Kumar, 2013; Wangen \& Faria, 2013; Moreira, Santos, \& Favarão, 2014;). Genotypes selected from field corn and popcorn germplasm have been identified as having the highest potential for baby corn production (Pereira \& Karam, 2008).
Despite the efforts invested in evaluating the performance of different corn genotypes with regard to baby corn production, the establishment of genetic parameters to determine selection strategies for superior genotypes is also crucial. Evaluating the general and specific combining ability of $\mathrm{S}_{2}$ families for baby corn production, Rodrigues, Silva and Mori (2004) reported that additive gene effects were more important for the trait expression of unhusked and husked ears. On the other hand, in a diallel analysis with popcorn lines, Camacho, Scapim, Senhorinho and Conrado (2014) observed a significant effect of both general and specific combining ability, indicating the predominance of additive and non-additive effects on the control of the main traits related to baby corn yield and quality.

Corn for baby corn production is cultivated in several regions of Brazil in notably diverse environments. Consequently, the phase of genotype evaluation for recommendation in different environments is seen as the key stage of breeding programs, in view of the importance of the genotype $x$ environment (GE) interaction on the evaluated traits. Three interaction situations are possible: the absence of an interaction, a simple interaction or a complex interaction. Under environmental variation, complex interactions cause inconsistency in the superior performance of genotypes, making it difficult to select and recommend new and improved cultivars (Cruz \& Carneiro, 2004). The possible methods for minimizing the effects of GE interaction are the identification of specific cultivars for each environment, ecological zoning or 
environmental stratification, or the identification of cultivars with higher phenotypic stability. However, the most recommended alternative for addressing these interactions is the selection of stable lines with wide adaptability (Ramalho, Santos, \& Zimmermann., 1993).

The objective of this study was to evaluate different field corn, popcorn, white corn, and sweet corn genotypes for their yield potential for baby corn and to evaluate the components of the genotypeenvironment interaction.

\section{Material and Methods}

Three experiments were carried out, one in the second growth season of 2011 in Maringá, PR $\left(23^{\circ} 11^{\prime} \mathrm{S}, 052^{\circ} 03^{\prime} \mathrm{W}\right.$ and $550 \mathrm{~m}$ asl) and the other two in the main growth season of 2011/2012 and second growth season of 2012 in Rio Verde, GO ( $17^{\circ} 47^{\prime} \mathrm{S}, 050^{\circ} 57^{\prime} \mathrm{W}$ and $753 \mathrm{~m}$ asl). The climate in the regions of Maringá and Rio Verde, according to the Köppen classification, are $\mathrm{Cfa}$ and $\mathrm{Aw}$, respectively. The soil in both experimental areas is classified as an Oxisol, and conventional tillage was used in all experiments.

The experiments were carried out in a randomized block design with three replications. Twenty-nine corn genotypes (Table 1) of popcorn, sweet corn, white corn and field corn were evaluated. The plots consisted of a 5-m long row with $0.9 \mathrm{~m}$ between rows. Sowing was performed by hand, leaving approximately 15 plants per meter after thinning, i.e., a final plant density of approximately 170 thousand plants per hectare.

Table 1

Relation of field corn, popcorn, white corn, and sweet corn genotypes, group type, genetic and breeding company

\begin{tabular}{ccccc}
\hline No. & Genotype & Group type & Genetic & Company \\
\hline 1 & Cidade Gaúcha & Popcorn & Compound & UEM \\
2 & Fracaro & Popcorn & Compound & UEM \\
3 & 2-misto & Popcorn & Compound & UEM \\
4 & 3-branco & Popcorn & Compound & UEM \\
5 & Mateus & Popcorn & Compound & UEM \\
6 & P3 & Popcorn & Synthetic & UEM \\
7 & P5 & Popcorn & Synthetic & UEM \\
8 & P8 & Popcorn & Synthetic & UEM \\
9 & P9 & Popcorn & Synthetic & UEM \\
10 & P11 & Popcorn & Synthetic & UEM \\
11 & IAC 112 & Popcorn & Single-cross hybrid & IAC \\
12 & IAC 125 & Popcorn & Single-cross hybrid & IAC \\
13 & Jade & Popcorn & Double-cross hybrid & PIONEER \\
14 & IPR 127 & White & Single-cross hybrid & IAPAR \\
15 & IPR 119 & White & Double-cross hybrid & IAPAR \\
16 & HT 392 & White & Triple-cross hybrid & Sementes Nascente \\
17 & 932 HT & White & Triple-cross hybrid & Sementes Nascente \\
18 & 5392 HT & White & Triple-cross hybrid & Sementes Nascente \\
19 & 9332 HT & White & Triple-cross hybrid & Sementes Nascente
\end{tabular}

continue 
continuation

\begin{tabular}{lcccc}
20 & HD 332 & White & Double-cross hybrid & Sementes Nascente \\
21 & IAC Nelore & White & Intervarietal hybrid & IAC \\
22 & Super doce & Sweet corn & Variety & EMBRAPA \\
23 & RB 6324 & Sweet corn & Single-cross hybrid & SYNGENTA \\
24 & BR 402 & Sweet corn & Variety & EMBRAPA \\
25 & P30K64 & Corn & Single-cross hybrid & PIONEER \\
26 & P3021 & Corn & Single-cross hybrid & PIONEER \\
27 & Fórmula & Corn & Single-cross hybrid & SYNGENTA \\
28 & CD 304 & Corn & Triple-cross hybrid & COODETEC \\
29 & CD 308 & Corn & Double-cross hybrid & COODETEC \\
\hline
\end{tabular}

In Maringá, sowing fertilization was performed with $350 \mathrm{~kg} \mathrm{ha}^{-1}$ of 04-14-08 N-P-K fertilizer and sidedressing with $75 \mathrm{~kg} \mathrm{~N} \mathrm{ha}^{-1}$ at morphological phase V4, with urea as the $\mathrm{N}$ source. In Rio Verde, both experiments were fertilized at sowing with 400 $\mathrm{kg} \mathrm{ha}^{-1}$ of 08-20-18 N-P-K and sidedressed with 90 $\mathrm{kg} \mathrm{N} \mathrm{ha}{ }^{-1}$ at morphological phase $\mathrm{V} 4$, with urea as the $\mathrm{N}$ source. Other cultural treatments were applied according to the development of the crops and the recommendations of Fancelli and Dourado Neto (2000), considering the environmental specificities of the different locations and growing seasons.

The harvests in the three experiments were performed between 7 and 9 a.m. to minimize ear dehydration. For each experiment, 10 harvests were carried out on alternate days in each plot. Ears with a style-stigma length of $1 \mathrm{~cm}$ to $3 \mathrm{~cm}$ were harvested at the R1 morphological stage for each genotype. The harvested ears were packed in plastic bags for subsequent straw removal and separation of commercial ears (diameter $8-18 \mathrm{~mm}$, length 4 $-12 \mathrm{~cm})$.

The following traits were evaluated: average ear length $(\mathrm{EL}, \mathrm{cm})$ and average ear diameter (ED, $\mathrm{mm}$ ) of 10 randomly chosen husked ears, measured with a graduated ruler and a digital pachymeter; prolificacy (PROL), calculated as the ratio between the number of commercial ears and the final plant density; and ear yield (YLD, $\mathrm{kg} \mathrm{ha}^{-1}$ ), corresponding to the weight of all commercial ears, weighed on a digital scale.

The data for all evaluated traits were subjected to individual analysis of variance. In the case of homogeneity of variances (a ratio between the largest and smallest mean square error $<7$ ), a combined analysis of variance was performed, considering genotype and environmental effects as fixed, according to the statistical model:

$$
Y_{i j k}=\mu+B_{k(j)}+G_{i}+A_{j}+G_{i} A_{j}+\varepsilon_{i j k}
$$

where $\mathrm{Y}_{\mathrm{ijk}}$ is the phenotypic measurement for each trait in the $i$-th genotype in the $k$-th block and $j$-th environment; is the overall mean; $\mathrm{B}_{\mathrm{k}}\left(\mathrm{A}_{\mathrm{j}}\right)$ is the effect of block $k$ on environment $j$; $A_{j}$ is the effect of the $j^{\text {th }}$ environment; $G_{i} A_{j}$ is the effect of the interaction between genotype $\mathrm{i}$ and environment $\mathrm{j}$; and $\varepsilon_{\mathrm{ijk}}$ is the random effect of the experimental error observed in plot ${ }_{\mathrm{ijk}}\left(\varepsilon_{\mathrm{ijk}} \sim \operatorname{NID}\left(0, \sigma^{2}\right)\right)$. Means were compared by the Scott-Knott test at $5 \%$ probability. The Scheffé test at $5 \%$ probability was applied to compare the differences among the grouped genotypes and the genetic bases.

The partitioning of the mean square of the interaction into simple and complex parts was estimated by the expression proposed by Cruz and Castoldi (1991), in which the complex part is expressed by the equation:

$$
C=\sqrt{(1-r)^{3} Q_{1} Q_{2}}
$$


where $Q_{1}$ and $Q_{2}$ are the mean squares of the genotypes at locations 1 and 2, respectively, and $r$ is the simple correlation coefficient between genotypes at both locations.

Based on the mean square expectations of the statistical model, the components of the genetic variance and GE interaction were estimated. The parameters of the phenotypic correlations were estimated to determine the degree to which the genotype performance was associated with the different environments. All statistical analyses were performed using the statistical software Genes (Cruz, 2013).

\section{Results and Discussion}

A summary of the analysis of variance for the evaluated traits is presented in Table 2. Significant effects were observed in the genotypes and the GE interaction for all evaluated traits except EL. This result shows the differentiated genotype performances in terms of suitability for baby corn production, apart from the need to compare the best genotypes within each evaluation environment. The calculated coefficients of variation can be classified as low compared with those from other baby corn experiments described in the literature (Dovale, Fritsche-Neto, \& Silva, 2011; Carvalho, Afférri, Pelúzio, Santos, \& Bicudo, 2014; Santos et al., 2014; Araújo et al., 2017), indicating a high experimental precision.

Table 2

Summary of combined analysis of variance for the evaluated traits of 29 corn genotypes, in the second growing season in Maringá - PR, and main and second growing seasons in Rio Verde - GO

\begin{tabular}{lccccc}
\hline \multirow{2}{*}{$\mathrm{SV}$} & $\mathrm{DF}$ & \multicolumn{4}{c}{ Mean Square } \\
\cline { 3 - 6 } & 6 & $\mathrm{EL}^{1}$ & $\mathrm{ED}^{2}$ & $\mathrm{PROL}^{3}$ & $\mathrm{YLD}^{4}$ \\
\hline Block/environment & 6.50 & 0.31 & 0.008 & 3990.0 \\
Environment (E) & 2 & $23.19 * *$ & $78.42 * *$ & $1.119^{* *}$ & $1234977.0 * *$ \\
Genotype (G) & 28 & $2.33 * *$ & $10.31 * *$ & $0.097 * *$ & $459103.9 * *$ \\
$\mathrm{GE}$ & 56 & $0.36 \mathrm{~ns}$ & $1.10^{*}$ & $0.057 * *$ & $112317.5 * *$ \\
$\mathrm{G} / \mathrm{A} 1^{5}$ & 28 & - & $4.22 * *$ & $0.094 * *$ & $305422.7 * *$ \\
$\mathrm{G} / \mathrm{A} 2^{6}$ & 28 & - & $3.32 * *$ & $0.067 * *$ & $258778.4 * *$ \\
$\mathrm{G} / \mathrm{A} 3^{7}$ & 28 & - & $4.96 * *$ & $0.050 * *$ & $119537.7 * *$ \\
\hline Error & 168 & 0.35 & 0.78 & 0.015 & 13658.0 \\
\hline $\mathrm{CV}(\%)$ & & 7.16 & 6.89 & 16.75 & 12.49 \\
\hline
\end{tabular}

${ }^{*}$ and $* *$ significant at 5 and $1 \%$ probability, respectively, by the $\mathrm{F}$ test. ${ }^{1} \mathrm{EL}(\mathrm{cm})$ : average ear length; ${ }^{2} \mathrm{ED}(\mathrm{mm})$ : average ear diameter; ${ }^{3} \mathrm{PROL}$ : prolificacy; ${ }^{4} \mathrm{YLD}\left(\mathrm{kg} \mathrm{ha}^{-1}\right)$ : ear yield per hectare; ${ }^{5} \mathrm{~A} 1$ : Maringá; ${ }^{6} \mathrm{~A} 2$ : Rio Verde (main growing season); ${ }^{7} \mathrm{~A} 3$ : Rio Verde (second growing season).

The differences among genotypes for dry grain yield are well documented in the literature and mostly result from differences in the adaptation capacity of varieties and hybrids (Sangoi et al., 2006; Mendes et al., 2012; Oliboni et al., 2013; Carvalho et al., 2014). In relation to baby corn yield, although the harvest is performed before ear fertilization, the results suggest that the variations in the means of the ear quality and yield components or related traits are also influenced by genetic and environmental factors. However, considering only EL, the genotype performance was similar in the three evaluation environments, suggesting that the best genotypes in a given environment also stood out in the other environments and that the effect of the environment, whether favorable or unfavorable, is similar for all genotypes. 
The evaluation of genotypes in different environments in order to identify and select the best genotypes according to the desired traits is characterized as one of the key stages of plant breeding (Resende, 2007). A differential response of the genotypes to environmental variations is frequently observed in field trials, making it difficult to identify the best genotypes (Cruz \& Carneiro, 2006).

The significance of the GE interaction can be divided into simple and complex parts; the former is due to differences among the evaluated genotypes, and the latter is due to the lack of association between the results in different environments. The complex part is a consequence of the lack of correlation between phenotype, genotype and environmental differences. This parameter is primarily associated with low phenotypic correlations, indicating that the genotypes that stand out in a specific environment do not perform as well in a different environment (Cruz \& Carneiro, 2006).
In corn grown for grain production, a significant GE interaction is very common, especially due to the action of environmental factors that influence the crop from the beginning to the end of the crop development cycle; a few of the evaluated genotypes likely account for the majority of the significance of the GE interaction (Cargnelutti \& Stork, 2009; Santos et al., 2011; Mendes et al., 2012; Carvalho et al., 2014).

The magnitudes of the quadratic components, presented in Table 3, also showed that the variation in YLD was minimally influenced by the effect of the GE interaction. In contrast, the expression of dry grain yield was governed by several genes that have small effect on the phenotype, which classifies dry grain yield as a quantitative characteristic with expression strongly influenced by the environment (Falconer \& Mackay, 1996). However, since baby corn yield is measured immediately after flowering in each genotype, the environmental influence on the ear development and grain filling stages may inflate the variance component of the GE interaction.

\section{Table 3}

Estimate of the genotypic correlation $\left(\widehat{\varphi}_{g}\right)$ and genotype - environment interaction $\left(\widehat{\varphi}_{g a}\right)$, Spearman correlations between environments and percentage of the complex part of the interaction for the evaluated traits in three experiments

\begin{tabular}{llcc}
\hline \multirow{2}{*}{ Parameter } & \multicolumn{3}{c}{ Traits } \\
\cline { 2 - 4 } & $\mathrm{ED}^{1}$ & PROL $^{2}$ & YLD $^{3}$ \\
\hline Quadratic components & & & \\
$\quad$ Genotypic correlation $\left(\hat{\varphi}_{g}\right)$ & 1.059 & 0.0092 & 37729.6 \\
$\quad$ Genotype - environment interaction $\left(\hat{\varphi}_{g a}\right)$ & 1.061 & 0.0139 & 32886.5 \\
\hline Complex part of the interaction $(\%)$ & & & 72.01 \\
$\quad$ Maringá x Rio Verde (main season) & 45.89 & 98.16 & 52.51 \\
$\quad$ Maringá x Rio Verde (second season) & 50.46 & 65.41 & 53.20 \\
$\quad$ Rio Verde: main x second season & 49.13 & 92.31 & \\
\hline Phenotypic correlation & & & $0.4746 * *$ \\
$\quad$ Maringá x Rio Verde (main season) & $0.7753 * *$ & $0.0173 \mathrm{~ns}$ & $0.5642 * *$ \\
$\quad$ Maringá x Rio Verde (second season) & $0.7385 * *$ & $0.4842 *$ & $0.6001 * *$ \\
$\quad$ Rio Verde: main x second season & $0.7222 * *$ & $0.1357 \mathrm{~ns}$ & \\
\hline
\end{tabular}

${ }^{n s}$ not significant. * ${ }^{* *}$, significant at $5 \%$ and $1 \%$ probability by the $\mathrm{t}$ test. ${ }^{1} \mathrm{ED}(\mathrm{mm})$ : mean ear diameter; ${ }^{2} \mathrm{PROL}$ : prolificacy; ${ }^{3} \mathrm{YLD}$ $\left(\mathrm{kg} \mathrm{ha}^{-1}\right)$ : ear yield per hectare. 
For ED, the percentage of the complex part of the interaction is lower and is associated with the highest estimates of phenotypic correlations. This suggests a similar performance of certain genotypes in different environments, regardless of the significance of the GE interaction (Table 3). For PROL and YLD, the percentages of the complex part of the interaction as well as the phenotypic correlations were mostly low to moderate, although they were still significant. This reinforces the increased difficulty of selection for promising genotypes in more than one environment. Therefore, it is possible to conclude that GE interaction influences the main traits related to baby corn yield and that baby corn breeding programs for YLD should focus on the evaluation of genotypes in different environments to estimate the adaptability and stability of the most promising genotypes.

The summary of the Scott-Knott test for EL and $\mathrm{ED}$ is shown in Table 4. For EL, a variation from $7.13 \mathrm{~cm}$ (Mateus) to $9.27 \mathrm{~cm}$ (Jade) was observed, while ED varied from $11.79 \mathrm{~mm}$ (P5) to 15.34 mm (CD 308) in Maringá, from $10.52 \mathrm{~mm}$ (P5) to $13.78 \mathrm{~mm}$ (HT 5392) in the summer in Rio Verde, and from $10.49 \mathrm{~mm}$ (Mateus) to $15.98 \mathrm{~mm}$ (Super doce) in the second season in Rio Verde (Table 4). It is noteworthy that the EL and ED of all evaluated genotypes met the quality standards required for commercial sale. According to Pereira Filho and Karam (2008), the length of commercial ears must be between 4 and $10 \mathrm{~cm}$, and the diameter must be between 10 and $15 \mathrm{~mm}$.

Table 4

Average ear length (EL) and average ear diameter (ED) of 29 corn genotypes evaluated in the main growing season in Maringá-PR and in the main and second growing seasons in Rio Verde-GO

\begin{tabular}{lcccc}
\hline \multirow{2}{*}{ Genotypes } & \multicolumn{3}{c}{ EL $^{1}$} & \multicolumn{2}{c}{ CD $^{2}$} & \\
\cline { 2 - 5 } & Mean & Maringá & Rio Verde & Rio Verde $^{4}$ \\
\hline Cidade Gaúcha & $8.1 \mathrm{~b}$ & $13.7 \mathrm{a}$ & $10.7 \mathrm{~b}$ & $11.7 \mathrm{~d}$ \\
Fracaro & $9.1 \mathrm{a}$ & $12.9 \mathrm{~b}$ & $12.2 \mathrm{a}$ & $11.5 \mathrm{~d}$ \\
2-mista & $8.5 \mathrm{a}$ & $12.4 \mathrm{~b}$ & $10.7 \mathrm{~b}$ & $12.1 \mathrm{c}$ \\
3-branca & $8.0 \mathrm{~b}$ & $12.7 \mathrm{~b}$ & $11.5 \mathrm{~b}$ & $11.2 \mathrm{~d}$ \\
Mateus & $7.1 \mathrm{c}$ & $12.0 \mathrm{~b}$ & $10.6 \mathrm{~b}$ & $10.5 \mathrm{~d}$ \\
P3 & $8.3 \mathrm{~b}$ & $12.8 \mathrm{~b}$ & $11.0 \mathrm{~b}$ & $11.4 \mathrm{~d}$ \\
P5 & $8.4 \mathrm{~b}$ & $11.8 \mathrm{~b}$ & $10.5 \mathrm{~b}$ & $10.9 \mathrm{~d}$ \\
P8 & $8.8 \mathrm{a}$ & $12.2 \mathrm{~b}$ & $11.6 \mathrm{~b}$ & $11.3 \mathrm{~d}$ \\
P9 & $8.3 \mathrm{~b}$ & $12.3 \mathrm{~b}$ & $10.8 \mathrm{~b}$ & $11.6 \mathrm{~d}$ \\
P11 & $8.0 \mathrm{~b}$ & $13.1 \mathrm{~b}$ & $10.6 \mathrm{~b}$ & $12.2 \mathrm{c}$ \\
IAC 112 & $8.6 \mathrm{a}$ & $12.7 \mathrm{~b}$ & $10.9 \mathrm{~b}$ & $12.5 \mathrm{c}$ \\
IAC 125 & $9.0 \mathrm{a}$ & $13.4 \mathrm{~b}$ & $11.2 \mathrm{~b}$ & $12.5 \mathrm{c}$ \\
Jade & $9.3 \mathrm{a}$ & $12.5 \mathrm{~b}$ & $11.2 \mathrm{~b}$ & $12.5 \mathrm{c}$ \\
IPR 127 & $7.7 \mathrm{c}$ & $15.3 \mathrm{a}$ & $12.8 \mathrm{a}$ & $13.3 \mathrm{~b}$ \\
IPR 119 & $8.7 \mathrm{a}$ & $14.5 \mathrm{a}$ & $11.7 \mathrm{~b}$ & $12.2 \mathrm{c}$ \\
HT 392 & $7.8 \mathrm{c}$ & $14.5 \mathrm{a}$ & $11.9 \mathrm{~b}$ & $11.8 \mathrm{~d}$ \\
932 HT & $7.6 \mathrm{c}$ & $15.1 \mathrm{a}$ & $12.4 \mathrm{a}$ & $13.7 \mathrm{~b}$ \\
HT 5392 & $7.7 \mathrm{c}$ & $14.0 \mathrm{a}$ & $13.8 \mathrm{a}$ & $12.2 \mathrm{c}$ \\
HT 9332 & $7.8 \mathrm{c}$ & $14.8 \mathrm{a}$ & $12.6 \mathrm{a}$ & $12.4 \mathrm{c}$ \\
HD 332 & $8.2 \mathrm{~b}$ & $14.7 \mathrm{a}$ & $12.8 \mathrm{a}$ & $12.8 \mathrm{c}$ \\
& & & & continue
\end{tabular}


continuation

\begin{tabular}{lcccc} 
IAC Nelore & $8.2 \mathrm{~b}$ & $15.3 \mathrm{a}$ & $12.8 \mathrm{a}$ & $14.3 \mathrm{~b}$ \\
Superdoce & $9.0 \mathrm{a}$ & $14.8 \mathrm{a}$ & $13.8 \mathrm{a}$ & $16.0 \mathrm{a}$ \\
RB 6324 & $8.3 \mathrm{~b}$ & $15.3 \mathrm{a}$ & $13.0 \mathrm{a}$ & $13.4 \mathrm{~b}$ \\
BR 402 & $8.1 \mathrm{~b}$ & $14.1 \mathrm{a}$ & $12.0 \mathrm{~b}$ & $12.4 \mathrm{c}$ \\
P30K64 & $8.2 \mathrm{~b}$ & $14.9 \mathrm{a}$ & $11.7 \mathrm{~b}$ & $12.7 \mathrm{c}$ \\
P3021 & $8.1 \mathrm{~b}$ & $14.8 \mathrm{a}$ & $12.7 \mathrm{a}$ & $12.2 \mathrm{c}$ \\
Fórmula & $9.1 \mathrm{a}$ & $14.8 \mathrm{a}$ & $13.3 \mathrm{a}$ & $14.1 \mathrm{~b}$ \\
CD 304 & $8.5 \mathrm{a}$ & $14.8 \mathrm{a}$ & $13.8 \mathrm{a}$ & $14.7 \mathrm{a}$ \\
CD 308 & $8.0 \mathrm{~b}$ & $15.3 \mathrm{a}$ & $12.8 \mathrm{a}$ & $14.9 \mathrm{a}$ \\
\hline Mean & 8.3 & 13.8 & 12.0 & 12.6 \\
\hline
\end{tabular}

Means followed by the same letter in a column did not differ significantly from each other by the Scott-Knott test at $5 \%$ probability. ${ }^{1} \mathrm{EL}(\mathrm{cm})$ : average ear length; ${ }^{2} \mathrm{ED}(\mathrm{mm})$ : average ear diameter; ${ }^{3}$ Rio Verde main season; ${ }^{4}$ Rio Verde second season.

A summary of the Scott-Knott test results for PROL and YLD is presented in Table 5. PROL is important because it indicates the ability of a genotype to generate progenies, which is decisive when the objective of corn cultivation is baby corn production, as this ability can make more than one harvest per plant possible. Differentiated genotype performances were observed in the tested environments, and the genotypes HT 392, HT 5392, IAC 112, IPR 119, P30K64, HT 9332, and IAC 125 stood out as promising, with better performance than the other genotypes in at least two environments (Table 5).

Table 5

Prolificacy (PROL) and ear yield (YLD) of 29 maize genotypes evaluated in the main growing season in Maringá-PR and in the main and second growing seasons in Rio Verde-GO

\begin{tabular}{|c|c|c|c|c|c|c|c|c|c|c|c|c|}
\hline \multirow{3}{*}{$\begin{array}{l}\text { Genotype } \\
\text { Cidade Gaúcha }\end{array}$} & \multicolumn{6}{|c|}{ PROL $^{1}$} & \multicolumn{6}{|c|}{ YLD $^{2}$} \\
\hline & \multicolumn{2}{|c|}{ Maringá } & \multicolumn{2}{|c|}{ Rio Verde 3} & \multicolumn{2}{|c|}{ Rio Verde ${ }^{4}$} & \multicolumn{2}{|c|}{ Maringá } & \multicolumn{2}{|c|}{ Rio Verde $^{3}$} & \multicolumn{2}{|c|}{ Rio Verde ${ }^{4}$} \\
\hline & 0.77 & $\mathrm{~b}$ & 0.59 & $\mathrm{c}$ & 0.66 & $\mathrm{a}$ & 896 & $\mathrm{~d}$ & 659 & $\mathrm{e}$ & 689 & $\mathrm{~b}$ \\
\hline Fracaro & 0.92 & $\mathrm{~b}$ & 0.75 & $\mathrm{c}$ & 0.31 & $\mathrm{~b}$ & 1189 & $\mathrm{~b}$ & 737 & d & 331 & $\mathrm{c}$ \\
\hline 2-mista & 0.78 & $\mathrm{~b}$ & 0.70 & $\mathrm{c}$ & 0.55 & $\mathrm{~b}$ & 793 & d & 526 & e & 700 & $\mathrm{~b}$ \\
\hline 3-branca & 0.82 & $\mathrm{~b}$ & 0.74 & $\mathrm{c}$ & 0.41 & $\mathrm{~b}$ & 807 & $\mathrm{~d}$ & 777 & $\mathrm{~d}$ & 479 & $\mathrm{c}$ \\
\hline Mateus & 0.45 & $\mathrm{~d}$ & 0.64 & $\mathrm{c}$ & 0.48 & $\mathrm{~b}$ & 441 & $\mathrm{f}$ & 688 & e & 552 & $\mathrm{c}$ \\
\hline P3 & 0.89 & $\mathrm{~b}$ & 0.53 & $\mathrm{c}$ & 0.54 & $\mathrm{~b}$ & 941 & $\mathrm{c}$ & 600 & $\mathrm{e}$ & 626 & $\mathrm{~b}$ \\
\hline P5 & 0.75 & $\mathrm{~b}$ & 0.62 & $\mathrm{c}$ & 0.80 & $\mathrm{a}$ & 748 & $\mathrm{e}$ & 522 & e & 785 & $\mathrm{~b}$ \\
\hline P8 & 0.58 & $\mathrm{c}$ & 0.59 & $\mathrm{c}$ & 0.49 & $\mathrm{~b}$ & 641 & $\mathrm{e}$ & 496 & e & 605 & $\mathrm{~b}$ \\
\hline P9 & 0.53 & $\mathrm{c}$ & 0.60 & $\mathrm{c}$ & 0.56 & $\mathrm{~b}$ & 685 & $\mathrm{e}$ & 630 & $\mathrm{e}$ & 747 & $\mathrm{~b}$ \\
\hline P11 & 0.89 & $\mathrm{~b}$ & 0.55 & $\mathrm{c}$ & 0.49 & $\mathrm{~b}$ & 963 & $\mathrm{c}$ & 443 & $\mathrm{e}$ & 719 & $\mathrm{~b}$ \\
\hline IAC 112 & 1.15 & $\mathrm{a}$ & 0.70 & $\mathrm{c}$ & 0.71 & $\mathrm{a}$ & 985 & $\mathrm{c}$ & 815 & d & 980 & $\mathrm{a}$ \\
\hline IAC 125 & 0.97 & $\mathrm{a}$ & 0.78 & $\mathrm{c}$ & 0.68 & $\mathrm{a}$ & 1200 & $\mathrm{~b}$ & 1025 & $\mathrm{c}$ & 993 & $\mathrm{a}$ \\
\hline
\end{tabular}




\begin{tabular}{lcccccccccccc} 
continuation & & & & & & & & & & & \\
Jade & 0.66 & $\mathrm{c}$ & 0.84 & $\mathrm{~b}$ & 0.46 & $\mathrm{~b}$ & 844 & $\mathrm{~d}$ & 803 & $\mathrm{~d}$ & 755 & $\mathrm{~b}$ \\
IPR 127 & 0.86 & $\mathrm{~b}$ & 0.85 & $\mathrm{~b}$ & 0.71 & $\mathrm{a}$ & 1341 & $\mathrm{~b}$ & 1166 & $\mathrm{c}$ & 1148 & $\mathrm{a}$ \\
IPR 119 & 0.96 & $\mathrm{a}$ & 0.95 & $\mathrm{~b}$ & 0.64 & $\mathrm{a}$ & 1448 & $\mathrm{a}$ & 1344 & $\mathrm{~b}$ & 1041 & $\mathrm{a}$ \\
HT 392 & 0.89 & $\mathrm{~b}$ & 1.12 & $\mathrm{a}$ & 0.76 & $\mathrm{a}$ & 1304 & $\mathrm{~b}$ & 1233 & $\mathrm{~b}$ & 1006 & $\mathrm{a}$ \\
HT 932 & 0.89 & $\mathrm{~b}$ & 0.85 & $\mathrm{~b}$ & 0.63 & $\mathrm{a}$ & 1333 & $\mathrm{~b}$ & 1137 & $\mathrm{c}$ & 966 & $\mathrm{a}$ \\
HT 5392 & 1.11 & $\mathrm{a}$ & 0.75 & $\mathrm{c}$ & 0.71 & $\mathrm{a}$ & 1450 & $\mathrm{a}$ & 1078 & $\mathrm{c}$ & 1023 & $\mathrm{a}$ \\
HT 9332 & 1.00 & $\mathrm{a}$ & 0.72 & $\mathrm{c}$ & 0.73 & $\mathrm{a}$ & 1441 & $\mathrm{a}$ & 1134 & $\mathrm{c}$ & 989 & $\mathrm{a}$ \\
HD 332 & 1.02 & $\mathrm{a}$ & 0.70 & $\mathrm{c}$ & 0.55 & $\mathrm{~b}$ & 1607 & $\mathrm{a}$ & 968 & $\mathrm{c}$ & 842 & $\mathrm{a}$ \\
IAC Nelore & 0.75 & $\mathrm{~b}$ & 0.66 & $\mathrm{c}$ & 0.64 & $\mathrm{a}$ & 1067 & $\mathrm{c}$ & 648 & $\mathrm{e}$ & 989 & $\mathrm{a}$ \\
Superdoce & 0.76 & $\mathrm{~b}$ & 0.87 & $\mathrm{~b}$ & 0.56 & $\mathrm{~b}$ & 711 & $\mathrm{e}$ & 1061 & $\mathrm{c}$ & 969 & $\mathrm{a}$ \\
RB 6324 & 0.88 & $\mathrm{~b}$ & 0.89 & $\mathrm{~b}$ & 0.72 & $\mathrm{a}$ & 1256 & $\mathrm{~b}$ & 1301 & $\mathrm{~b}$ & 948 & $\mathrm{a}$ \\
BR 402 & 0.37 & $\mathrm{~d}$ & 1.05 & $\mathrm{a}$ & 0.35 & $\mathrm{~b}$ & 504 & $\mathrm{f}$ & 1167 & $\mathrm{c}$ & 531 & $\mathrm{c}$ \\
P30K64 & 0.80 & $\mathrm{~b}$ & 1.02 & $\mathrm{a}$ & 0.68 & $\mathrm{a}$ & 996 & $\mathrm{c}$ & 1529 & $\mathrm{a}$ & 974 & $\mathrm{a}$ \\
P3021 & 0.84 & $\mathrm{~b}$ & 0.85 & $\mathrm{~b}$ & 0.70 & $\mathrm{a}$ & 1033 & $\mathrm{c}$ & 1317 & $\mathrm{~b}$ & 1009 & $\mathrm{a}$ \\
Fórmula & 0.91 & $\mathrm{~b}$ & 0.74 & $\mathrm{c}$ & 0.81 & $\mathrm{a}$ & 1415 & $\mathrm{a}$ & 906 & $\mathrm{~d}$ & 878 & $\mathrm{a}$ \\
CD 304 & 0.74 & $\mathrm{~b}$ & 0.68 & $\mathrm{c}$ & 0.52 & $\mathrm{~b}$ & 1348 & $\mathrm{~b}$ & 900 & $\mathrm{~d}$ & 835 & $\mathrm{a}$ \\
CD 308 & 0.88 & $\mathrm{~b}$ & 0.82 & $\mathrm{~b}$ & 0.61 & $\mathrm{a}$ & 1430 & $\mathrm{a}$ & 1011 & $\mathrm{c}$ & 856 & $\mathrm{a}$ \\
\hline Mean & 0.82 & & 0.76 & & 0.60 & & 1063 & & 918 & & 827 & \\
\hline
\end{tabular}

Means followed by the same letter in a column did not differ significantly from each other by the Scott-Knott test at $5 \%$ probability. ${ }^{1}$ PROL: prolificacy; ${ }^{2}$ YLD $\left(\mathrm{kg} \mathrm{ha}^{-1}\right)$ : ear yield per hectare; ${ }^{3}$ Rio Verde main season; ${ }^{4}$ Rio Verde second season.

The genotype response differed between environments for YLD, with mean variations in Maringá (from $441 \mathrm{~kg} \mathrm{ha}^{-1}$ - Mateus to $1607 \mathrm{~kg}$ $\mathrm{ha}^{-1}$ - HD 332), in the summer in Rio Verde (from $443 \mathrm{~kg} \mathrm{ha}^{-1}$ - P11 to $1529 \mathrm{~kg} \mathrm{ha}^{-1}$ - P30K64) and in the second season in Rio Verde (from $331 \mathrm{~kg} \mathrm{ha}^{-1}$ Fracaro to $1148 \mathrm{~kg} \mathrm{ha}^{-1}$ - IPR 127). The genotypes HD 332, HT 5392, IPR 119, HT 9332, CD 308, and Fórmula outperformed the others in Maringá, while in summer in Rio Verde, the YLD of the field corn hybrid P30K64 significantly exceeded those of the other genotypes. In the second season in Rio Verde, 17 genotypes produced higher mean ear yields than in the first season, including two popcorn hybrids (IAC 112 and IAC 125), all white corn and field corn genotypes, and all of the sweet corn genotypes, except variety BR402.

The mean ear yields of most genotypes were similar to those reported by Carvalho, Pinho and Rodrigues (2003) in an assessment of genotypes in three seasons (means from $430 \mathrm{~kg} \mathrm{ha}^{-1}$ of a popcorn genotype called "Pipoca-estéril" to $1340 \mathrm{~kg} \mathrm{ha}^{-1}$ of a field corn genotype, DKB929). The authors also reported the occurrence of a significant interaction between genotypes and seasons, and they emphasized that the field corn genotype DKB929 stood out for excellent yields in all three seasons. The results are also similar to those observed by Wangen and Faria (2013), who reported an ear yield of 759.6 $\mathrm{kg} \mathrm{ha}^{-1}$ for the field corn variety Al Piratininga and $1172 \mathrm{~kg} \mathrm{ha}^{-1}$ for the sweet corn genotype Tropical Plus, although the authors observed no significant differences between the genotypes.

In general, the YLD means of the evaluated genotypes exceeded those reported by Moreira et al. (2014), from $282.4 \mathrm{~kg} \mathrm{ha}^{-1}$ for the super sweet corn genotype Hawaii to $897.0 \mathrm{~kg} \mathrm{ha}^{-1}$ for the field corn genotype ATL200. The authors highlight the favorable performance of sweet corn and field corn genotypes for the traits related to the yield and commercial quality of baby corn. 
In breeding programs focused on the development of genotypes for corn that is to be consumed fresh or with minimal processing, sensory tests are essential to determine the acceptance level of the product as well as the preference of the end consumer for certain qualitative traits (Oliveira, Deliza, BressanSmith, Pereria, \& Chiquiere, 2006; Camilo et al., 2015). One of the limiting factors is the diversity of genotypes used to produce baby corn, which considerably increases the need for sensory analyses or the establishment of profiles of consumer sensory acceptance by expert tasters. Thus, the best genotypes have to be selected according to the different genetic bases, based on their desirable agronomic traits, which reduces the final number of genotypes in sensory tests.

The results of the comparisons between the different genetic bases with the Scheffé test are shown in Table 6. In terms of EL, no significant contrasts were observed between genotype groups, whereas popcorn and the other genotype groups differed significantly in ED. Considering the observed means, ear diameters were smaller in the popcorn than in the white corn, sweet corn and field corn genotypes. This result can be explained by the fact that popcorn genotypes have a lower number of grain rows per ear than the other genetic groups of corn (Ziegler, 2001).

Table 6

Estimate and significance of the contrasts between the different genetic bases of the tested genotypes

\begin{tabular}{|c|c|c|c|c|c|c|c|c|c|c|c|}
\hline \multirow{2}{*}{ Traits } & \multicolumn{11}{|c|}{ Contrasts } \\
\hline & $\mathrm{PP}^{7} v s^{8} \mathrm{U}$ & & ${\mathrm{PP} v s^{9} \mathrm{~S}}^{9}$ & & $\mathrm{PP} v s^{10} \mathrm{~F}$ & & $\mathrm{WC} v s \mathrm{SC}$ & & $\mathrm{WC} v s \mathrm{FC}$ & $\mathrm{SCvsFC}$ & \\
\hline $\mathrm{MEL}^{1}$ & 0.47 & & 0.04 & & 0.07 & & -0.51 & & -0.54 & -0.03 & \\
\hline MED²-Maringá & -2.11 & $*$ & -2.09 & & -2.27 & $*$ & 0.02 & & -0.17 & 0.19 & \\
\hline MED-Rio Verde ${ }^{5}$ & -1.57 & $*$ & -1.87 & & -1.82 & $*$ & -0.30 & & -0.25 & 0.05 & \\
\hline MED-Rio Verde ${ }^{6}$ & -1.16 & & -2.24 & * & -2.05 & $*$ & -1.08 & & -0.89 & 0.20 & \\
\hline PROD $^{3}$-Maringá & -0.15 & & 0.11 & & -0.05 & & 0.27 & & 0.101 & -0.16 & \\
\hline PROD-Rio Verde & -0.16 & & -0.27 & & -0.16 & & -0.11 & & 0.003 & 0.11 & \\
\hline PROD-Rio Verde ${ }^{6}$ & -0.12 & & 0.01 & & -0.11 & & 0.13 & & 0.007 & -0.12 & \\
\hline YLD4-Maringá & -517.5 & $*$ & 32.7 & & -388.0 & $*$ & 550.2 & $*$ & 129.5 & -420.7 & * \\
\hline YLD-Rio Verde ${ }^{5}$ & -418.7 & $*$ & -505.5 & * & -461.8 & $*$ & -87.8 & & -44.1 & 43.7 & \\
\hline YLD-Rio Verde ${ }^{6}$ & $-311 .$. & $*$ & -126.7 & & -221.1 & & 184.5 & & 90.1 & -94.4 & \\
\hline
\end{tabular}

* significant at $5 \%$ probability by the Scheffé test. ${ }^{1} \mathrm{MED}(\mathrm{mm})$ : mean ear diameter; ${ }^{2} \mathrm{PROD}$ : productivity; ${ }^{3} \mathrm{YLD}\left(\mathrm{kg}\right.$ ha $\left.{ }^{-1}\right)$ : ear yield per hectare; ${ }^{5}$ main growing season; ${ }^{6}$ second growing season; ${ }^{7} \mathrm{PP}$ : popcorn; ${ }^{8} \mathrm{WC}$ : white corn; ${ }^{9} \mathrm{SC}$ : sweet corn; ${ }^{10} \mathrm{FC}$ : field corn.

No significant differences in EL or ED were detected by Wangen and Faria (2013) between five field corn, popcorn and sweet corn genotypes evaluated in Minas Gerais. On the other hand, Moreira et al. (2014) also observed significantly lower ED in popcorn genotypes than in the other corn groups, whereas the authors found no significant differences in EL between field corn and popcorn genotypes.
For PROL, no significant differences between the different genetic bases were detected, independent of the environment of evaluation. Therefore, the high plant populations used for baby corn cultivation allowed good productivity for all corn types used in the experiments. For YLD, on the other hand, the contrasts between the popcorn and the sweet, white and field corn genotypes were mostly significant in the three evaluated environments (Table 6), 
highlighting the differential response of different genotypes caused by environmental variations. The significant contrasts between the white corn group and the sweet corn group are also noteworthy, as well as those between the sweet and field corn genotypes. In the field trial carried out in MaringáPR, the white corn genotypes outperformed the field corn genotypes for the evaluated traits.

\section{Conclusions}

The genotype performance differed according to the environments for mean ear diameter, prolificacy, and ear yield. Genotypes P30K64, HD 332, IPR 119 , and IAC 125 showed the highest means for the evaluated traits. The groups of white and field corn genotypes outperformed the others, particularly with regard to ear yield.

\section{References}

Araújo, E. D., Feitosa, F. M., Silva, F. C. S., Andrade, I. O., Jr., Rodrigues, B. R. A., \& Mota, W. F. (2017). Growth and yield of baby corn as influenced by nitrogen topdressing. African Journal of Agricultural Research, 12(12), 936-969. doi: 10.5897/ AJAR2016.11931.

Camacho, L. R. S., Scapim, C. A., Senhorinho, H. J. C., Conrado, T. V. (2015). Diallel analysis of popcorn lines and hybrids for baby corn production. Crop Breeding and Applied Biotechnology, 15(1), 33-39. doi: 10.1590/1984-70332015v15n1n5.

Camilo, J. S., Barbieri, V. H. B., Rangel, R. M., Bonnas, D. S., Luiz, J. M. Q., Oliveira, R. C. (2015). Aceitação sensorial de híbridos de milho doce e híbridos de milho verde em intervalos de colheita. Revista Ceres, 62(1), 001-008. doi: 10.1590/0034737X201562010001.

Cargnelutti, A., Fº., \& Storck, L. (2009). Medidas do grau de precisão experimental em ensaios de competição de cultivares de milho. Revista Brasileira de Zootecnia, 44(2), 111-117. doi: 10.1590/S0100204X2009000200001.

Carvalho, E. V., Afférri, F. S., Pelúzio, J. M., Santos, W. F., Bicudo, S. J. (2014). Adaptabilidade na produção de massa verde e grãos de genótipos de milho no
Tocantins. Revista Ciência Agronômica, 45(4), 856862. doi: 10.1590/S1806-66902014000400025

Carvalho, G. S., Pinho, R. L. V., Rodrigues, V. N. (2003). Produção de minimilho em diferentes ambientes de cultivo. Revista Ceres, 50(288), 155-169.

Cruz, C. D. (2013). GENES: A software package for analysis in experimental statistics and quantitative genetics. Acta Scientiarum Agronomy, 35(3), 271276. doi: 10.4025/actasciagron.v35i3.21251.

Cruz, C. D., \& Carneiro, P. C. S. (2006). Modelos biométricos aplicados ao melhoramento genético (2a ed.). Viçosa, MG: Universidade Federal de Viçosa.

Cruz, C. D., \& Castoldi, F. L. (1991). Decomposição da interação genótipos x ambientes em partes simples e complexa. Revista Ceres, 38(219), 422-430.

Dovale, J. C., Fritsche-Neto, R., Silva, P. S. L. (2011). Índice de seleção para cultivares de milho com dupla aptidão: minimilho e milho verde. Bragantia, 70(4), 781-787. doi: 10.1590/S0006-87052011000400008.

Falconer, D. S., \& Mackay, T. F. C. (1996). Introduction to quantitative genetics (4nd ed.). London: Longman.

Fancelli, A. L. \& Dourado Neto, D. (2000). Produção de milho (1a ed.). Guaíba: Agropecuária.

Mendes, F. F., Guimarães, L. J. M., Souza, J. C., Guimarães, P. E. O., Pacheco, C. A. P., Machado, J. R. A., ..., Parentoni, S. N. (2012). Adaptability and stability of maize varieties using mixed model methodology. Crop Breeding and Applied Biotechnology, 12(2), 111-117. doi: 10.1590/S198470332012000200003.

Moreira, A., Santos, M. Z., Favarão, S. C. M. (2014). Características agronômicas de genótipos de milho para produção de minimilho. Revista em Agronegócios e Meio Ambiente, 7(3), 633-643.

Oliboni, R., Faria, M. V., Neumann, M., Resende, J. T. V., Battistelli, G. M., Tegoni, R. G., Oliboni, D. F. (2013). Análise dialélica na avaliação do potencial de híbridos de milho para a geração de populações base para obtenção de linhagens. Semina, 34(1), 7-18. doi: 10.5433/1679-0359.2013v34n1p7.

Oliveira, L. F. G., Jr., Deliza, R., Bressan-Smith, R., Pereira, M. G., Chiquiere, T. B. (2006). Seleção de genótipos de milho mais promissores para o consumo in natura. Ciência e Tecnologia de Alimentos, 26(1), 159-165. doi: 10.1590/S0101-20612006000100026.

Pereira, I. A., Fo., Borghi, E. (2016). Mercado de sementes no Brasil, safra 2016/2017. Sete Lagoas: EMBRAPA Milho e Sorgo. 
Pereira, I. A., Fo., Gama, E. E. G., Cruz, J. C. (1998). Minimilho: efeito de densidade de plantio e cultivares na produção e em algumas características da planta de milho. Sete Lagoas: Embrapa Milho e Sorgo.

Pereira, I. A. Fo., \& Karam D. (2008). A cultura do minimilho. Brasília, DF: Embrapa Informação Tecnológica.

Pereira. I. A., F ., Cruz, J. C., Queiroz. V. A. V., Caxito. A. M., Leite. C. E. P., Carmo. Z. C. (2009). Avaliação de cultivares de milho visando à produção de minimilho na região Norte do Estado de Minas Gerais. Sete Lagoas: Embrapa Milho e Sorgo.

Ramalho, M. P., Santos, J. B., Zimmermann, M. J. (1993). Interação Dos Genótipos Por Ambientes. In: Ramalho, M. P., Santos, J. B., Zimmermann, M. J. Genética quantitativa em plantas autógamas: aplicações ao melhoramento do feijoeiro. (1a ed., Cap 6, pp. 130-144). Goiânia: Universidade Federal de Goiás.

Reddy, S. M., Kumar, S. S., Sudharshan, M. R., Kumar, V. K. (2013). Genetic divergence in baby corn (Zea mays L.). International Journal of Innovative Research \& Development, 2(8), 300-304.

Resende, M. D. V. (2007). Matemática e estatística na análise de experimentos e no melhoramento genético. Colombo: Embrapa Florestas.

Rodrigues, L. R.; Silva, F. N.; Mori, E. S. (2004). Avaliação de sete famílias s2 prolíficas de minimilho para a produção de híbridos. Bragantia, 63(1), 3138. doi: 10.1590/S0006-87052004000100004.
Sangoi, L., Ernani, P. R., Silva, P. R. F., Horn, D., Schimitt, A., Schweitzer, C., Motter, F. (2006). Rendimento de grãos e margem bruta de cultivares de milho com variabilidade genética contrastante em diferentes sistemas de manejo. Ciência Rural, 36(3), 747-755. doi: 10.1590/S0103-84782006000300005.

Santos, E.L., Garbuglio, D. D., Araujo, P. M., Gerage, A. C., Shioga, P. S., Prete, C. E. C. (2011). Uni and multivariate methods applied to studies of de adaptability in maize (Zea mays L.). Acta Scientiarum Agronomy, 33(4), 633-640. doi: 10.4025/actasciagron.v33i4.6953.

Santos, R.F. Inoue, T. T., Scapim, C. A., Clovis, L. R., Moterle, L. M., Saraiva, F. C. S. (2014). Produtividade do minimilho em função das adubações nitrogenada e potássica. Revista Ceres, 61(1), 121-129. doi: 10.1590/S0034-737X2014000100016.

Teles, D. A. A. \& Nascimento, W. M. Competição de cultivares de milho-doce para produção de minimilho. Horticultura Brasileira, 28(2), 25622568, 2010.

Wangen, D. R. C. \& Faria, A. C. (2013). Avaliação de variedades de milho para produção de minimilho. Enciclopédia Biosfera, 9(17), 385-392.

Ziegler, K. E. (2001). Popcorn. In A. R. Hallauer. Specialty corns (Vol. 1, Chap. 7, pp. 205-240). New York: CRC Press LLC. 